\title{
Diagnostic assessment on vegetation damage due to hydrofluoric gas leak accident and restoration planning to mitigate the damage in a forest ecosystem around Hube Globe in Gumi
}

\author{
Kim, Gyung Soon ${ }^{* * *} \cdot$ An, Ji Hong ${ }^{*} \cdot$ Lim, Chi Hong ${ }^{*} \cdot$ Lim, Yun Kyung ${ }^{*} \cdot J u n g$, Song Hie ${ }^{*} \cdot$ Lee, Chang Seok ${ }^{* * *}+$ \\ "Department of Biology, Graduate School of Seoul Women's University, Seoul 139-774, Korea \\ * *National Institute of Ecology \\ * " "Department of Bio and Environmental Technology, Seoul Women's University, Seoul 139-774, Korea

\section{구미 휴브글로브 주변 삼림생태계에서 불화수소가스 유출 사고에 기인한 식생피해 진단 및 그 피해를 완화시키기 위한 복원 계획}

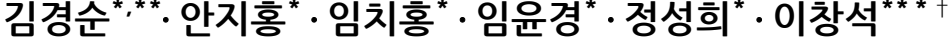 \\ *서울여자대학교 대학원 생물학과, ${ }^{* *}$ 국립생태원, ${ }^{* * *}$ 서울여자대학교 생명환경공학과 \\ (Received: 05 August 2014, Revised: 20 August 2014, Accepted: 13 December 2014)
}

\begin{abstract}
We obtained the following results from investigation on vegetation damage from 5 to 6 August, 2013, about one year after an accident that hydrofluoric acid leaked from a chemical maker, Hube Globe in Gumi. Pinus densiflora and Pinus strobus showed very severe damage. Ginko biloba, Quercus acutissima, Pinus rigida, Salix glandulosa, Hibiscus syriacus, and Lagerstroemia indica showed severe damage. Quercus variabilis, Lespedeza cyrtobotrya, and Miscanthus sinensis showed moderate damage. Quercus aliena, Smilax china, Arundidinella hirta, Ailanthus altissima, Robinia pseudoacacia, and Paulowinia coreana showed slight damage. We did not find any plants without leaf damage around there. This result means that fluoride damage still persists in this area as was known that fluoride remains for a long time in air, soil and water and exerts negative effects at all levels of an ecosystem. In addition, fluoride content contained in plant leaf depended on the distance from a fertilizer producing factory and vegetation damage tended to proportionate to the concentration in the Yeocheon industrial complex. In these respects, a measure for removal or detoxification of the remaining fluoride is urgently required around the hydrofluoric acid leak spot. Fertilizing of dolomite containing $\mathrm{Ca}$ and $\mathrm{Mg}$, which can trap fluoride, was prepared as one of the restoration plans. In addition, phosphate fertilizing was added in order to enhance soil ameliorating effects. Furthermore, we recommend the introduction of tolerant plants as the second measure to mitigate fluoride damage. As the tolerant plants to make a new forest by replacing trees died due to hydrofluoric acid gas damage, we recommended Q. aliena and $S$. china, A. hirta, etc. were recommended as plant species to add mantle vegetation to the forest margin to ensure stable interior environment of the forest.
\end{abstract}

Key words : Fluoride, Hydroflouric acid leak, restoration, soil amelioration, tolerant plant, vegetation damage

요 약

구미의 화학약품 제조업체 휴브글로브에서 불산 유출사고가 발생하고 약 1년 후인 2013년 8월 초 사고 발생 현장 주변에 성립한 식생 피해에 대한 조사를 통해 다음과 같은 결과를 얻었다. 소나무와 스트로브잣나무는 매우 심한 피해, 은행나무, 상수리나무, 리기다소나무, 왕버들, 무궁화 및 배롱나무는 심한 피해, 굴참나무, 참싸리 및 참억새는 중간수준의 피해 그리고 갈참나무, 청미래덩굴, 새, 아까시나무 및 오동은 가벼운 피해를 나타내었다. 우리는 피해 현장 주변에서 피해를 입지 않은 어떤 식물도 발견하지 못하였다. 이러한 결과는 불소가 대기, 토양 및 물에 오랫동안 남아 생태계의 모든 수준에 걸쳐 부정적인 영향을 미친다고 알려졌듯이 이 지역에서 지난 해 발생한 불소피해가 여전히 지속되고 있다는 것을 의미한다. 한편, 여천공업단지에서 조사된 결과에 의하면, 식물 잎에 포함된 불소 농도는 비료공장으로부터 거리에 따라 달라졌고 식생 피해는 그 농도에 비례하는 경향이었다. 이런 점에서 불산 유출사고 현장 주변 생태계에 잔존하는 불소의 제거 및 해독 대책이 시급히 요청되고 있다. 불소를 불활성화 시킬 수 있는 칼슘과 마그네슘을 함유하고 있는 돌로마이트의 시비가 그 피해를 완화시킬 수 있는 복원계획의 하나로 준비되었다. 그밖에 토양개량 효과를 증진시키기

\footnotetext{
${ }^{\dagger}$ To whom correspondence should be addressed.

Department of Bio and Environmental Technology, Seoul Women's

University, Seoul 139-774, Korea

E-mail: leecs@swu.ac.kr
} 
위해 인산염 비료 시비가 복원계획으로 추가되었다. 나아가 우리는 불소피해를 완화시키기 위한 두 번째 대책으로 내성종의 도입을 추천하였다. 불소가스 피해로 고사된 나무들을 대체하여 새로운 솦을 만들기 위한 내성종으로 우리는 갈참나무를 추천하였고, 그 숲이 안정된 내부 환경을 확보하기 위한 망토군락을 이룰 식물 종으로는 청미래덩굴과 새를 추천하였다.

핵심용어 : 내성식물, 복원, 불산 유출, 불소, 식생피해, 토양개량

\section{Introduction}

It is well known that industrial installations producing bricks, phosphate fertilizers, and glass, along with coal-fired power stations and aluminum smelters, are the most important sources of gaseous and particulate fluoride pollution (Mezghani et al., 2005).

Fluorine, unlike sulphur, nitrogen, and even chlorine, is not an essential element for plants. Because the natural occurrence of fluoride in the air is usually close to the detection limit, and plants take up little from the soil, the background concentration in plants is generally quite low (often as low as 1 and usually less than $10 \mu \mathrm{g} \mathrm{F} / \mathrm{g}$ dry weight in most species) (Weinstein 1977). Since HF and $\mathrm{SiF}_{4}$ are between 1 and 3 orders of magnitude more toxic than other common pollutants (e.g., $\mathrm{O}_{3}, \mathrm{SO}_{2}, \mathrm{PAN}, \mathrm{Cl}_{2}$, or $\mathrm{HCl}$ ), relatively small releases of fluorides into the atmosphere can result in extensive damage to plant (Weinstein and Davison, 2003)

Gaseous fluorides are absorbed through leaf stomata and move by transpiration into the principal sites of accumulation at the tip and leaf margins (Jacobson et al., 1966), where they can cause physiological, biochemical, and structural damage, and even cell death, depending on the concentration in the cell sap (Haidouti et al., 1993; Miller, 1993). In addition to direct uptake through their stomata, plants can incorporate fluoride from contaminated soils (Domingos et al., 2003). However, in highly polluted areas, direct absorption of airborne fluorides by plant foliage normally masks any soil uptake (Vike and Håbjø rg, 1995).

Fluorides in general, are accumulated in the plant tissues over long times. The injury symptoms are produced only after a critical level of fluoride is attained. Due to such accumulation over long times, fluorides generally and hydrogen fluoride (abbreviated as HF hereafter) particularly can induce injury at very low atmospheric concentrations. Critical concentration for fluoride injury is $0.1 \mathrm{ppm}$ for several days. Toxicity of particulate fluorides depends upon the particle size, their solubility and humidity of the atmosphere. HF gas is much lighter than air and so can cause damage in plants even at a distance of $30 \mathrm{~km}$ from the source. It is a hygroscopic gas and forms acidic cloud near the source (Gheorghe and Ion, 2011).

We have already experienced severity of gaseous fluoride damage in the forest ecosystem around the industrial complexes. In fact, the damage degree tended to proportionate to the fluoride concentration in the Yeocheon and the Ulsan industrial complexes where the ecosystem damage is very severe (NIER, 1984, Lee et al., 2004). We wonder the similar damage because the same kind of air pollutant was released on the ecosystem around the Gumi industrial complex although the source is different.

This study aims to report the results that we diagnosed on the ecosystem around the Hube Globe in Gumi where the hydrofluoric acid leaked before about one year. Furthermore, we also aim to recommend a restoration plan to mitigate the damage.

\section{Method}

\subsection{Study area}

This study was carried out in mountainous land around the village and around the residential area between Bongsan-ri and Yimcheon-ri, Sandong-myun, Gumi-si, Gyungsangbuk-do, South-eastern Korea where Hube Globe is located (Fig. 1). Mountainous land of gentle slope in this area is usually covered with Korean red pine (Pinus densiflora) community and Quercus acutissima community and Pinus rigida plantation appears in small size. Lowland and flatland are occupied by rice paddy, upland field, developed area including residential area, etc.

Pollution damage was investigated for plants, which compose forest vegetation and are introduced for landscaping around the residential area.

\subsection{Method}

Field survey was carried out from 5 to 6 August, 2013. Field survey was carried out by recording the damage degree of plant species growing around the Hube Globe in Gumi. Degree of leaf surface injury was evaluated as percentage of necrosis area visible to the 


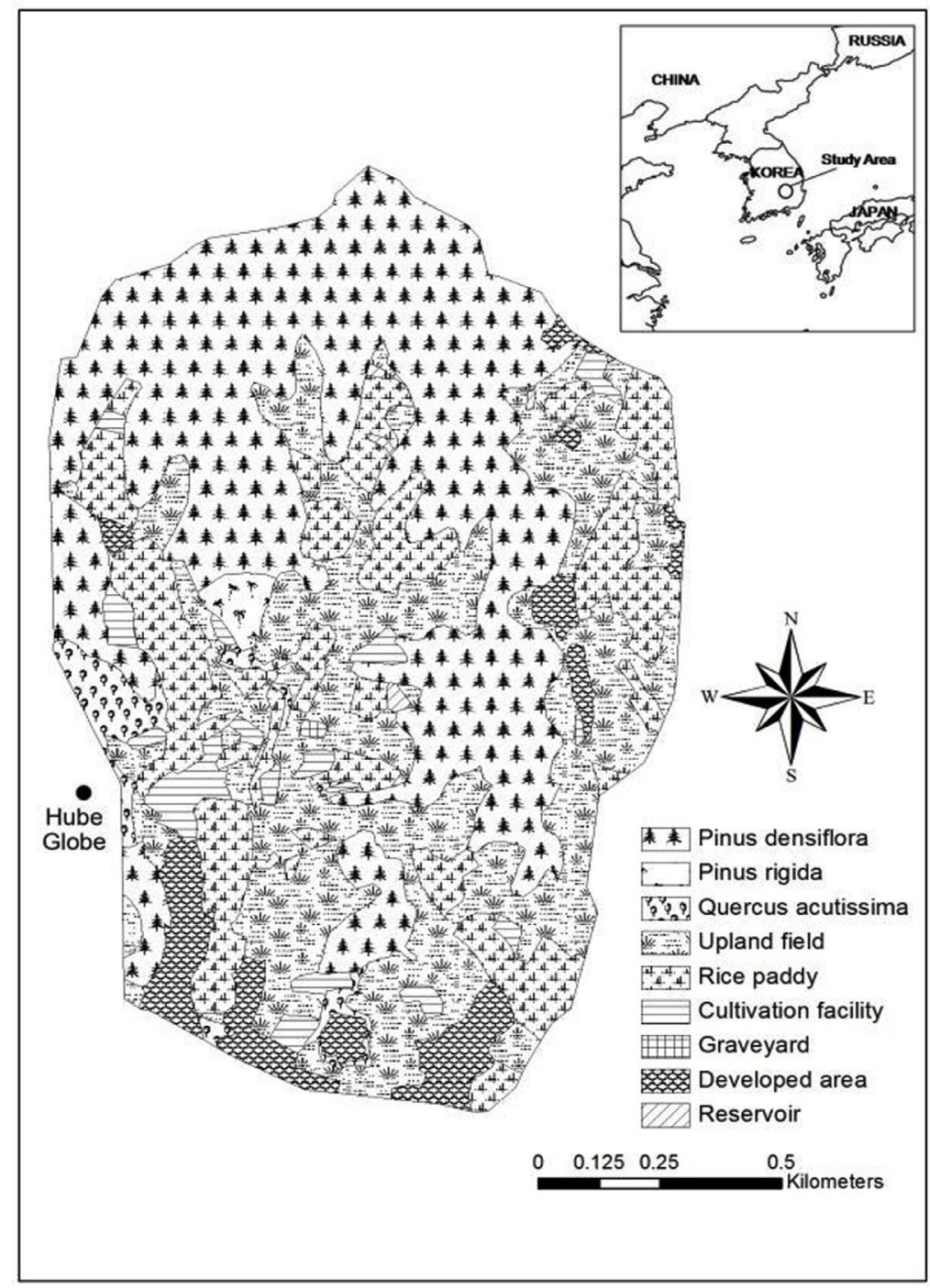

Fig. 1. A map showing the land use pattern of the study area.

naked eye relative to total leaf area through field survey. Degree of leaf surface injury was classified into five groups: very severe (more than $75 \%$ of total leaf area damaged), severe (50-75\% damaged), moderate (25$50 \%$ damaged), slight (less than 25\% damaged) and none (no damaged) (Lee et al., 2004).

Vegetation map of the Yeocheon industrial complex was prepared by analyzing aerial photos taken in 1990 . And HF concentration in 1984 when vegetation damage due to air pollution was very severe was obtained from NIER (1984).

\section{Results}

Most Korean red pines ( $P$. densiflora) growing in forest around the Hube Globe were died. P. strobus, which was introduced for hedge of a home, showed a feature just before withering that most of needles were damaged very severely.

$G$. biloba planted as the street tree showed severe damage although it is known as air pollution tolerant. In case of $Q$. acutissima, which composes a forest near to village in most areas in Korea, leaf shape as well as leaf color were changed severely. P. rigida, which was introduced for plantation, $S$. glandulosa planted in streamside to prevent flooding damage, and $H$. syriacus and $L$. indica introduced for landscaping around the village garden showed severe damage too.

Q. variabilis and a leguminous shrub, L. cyrtobotrya, showed moderate damage. $M$. sinensis, which is very tolerant to the air pollution and thereby dominate the forest ecosystem around the Yeocheon and the Ulsan industrial complexes showed also moderate damage.

Q. aliena, which is known as very strong air pollution tolerant (Lee et al. 2004, 2007), showed slight leaf damage. S. china, A. hirta, A. altissima, and $R$. 
Table 1. Plant group classified based on the visible damage shown on leaves of plant species appeared around the spot where hydrofluoric acid is released.

\begin{tabular}{cccc}
\hline Very severe & Severe & Moderate & Slight \\
\hline \hline & G. biloba & & Q. Aliena \\
& Q. acutissima & Q. variabilis & P. coreana \\
P. densiflora & P. rigida & L. cyrtobotya & S. china \\
P. strobus & S. glandulosa & M. sinensis & A. hirta \\
& H. syriacus & & A. altissima \\
& L. indica & R. pseudoacacia \\
\hline
\end{tabular}

pseudoacacia, which appeared frequently in the forest around the Yeocheon and the Ulsan industrial complexes and $P$. coreana planted around the village showed the same level of the tolerance as Q. aliena.

As is shown in the previously mentioned results, we could not find any plants without any leaf damage around there (Table 1). But we could find a difference among species in the degree that they are damaged. We evaluated the tolerance level of plant species based on the results. We determined the species damaged slightly as the tolerant species, whereas the species injured severely as the sensitive one (Lee et al., 2004).

\section{Discussion}

\subsection{Relationship between fluoride concentration and vegetation damage}

Land use pattern in the Yeocheon industrial complex is divided clearly depending on topographic condition. Upland is covered with forest, whereas lowland is with industrial area and agricultural field. Industrial area is restricted to the northern lowland, whereas agricultural field is dividing the other lowland with the residential (urbanized) area. Forest of this area before industrialization had usually covered with $P$. densiflora - Pinus thunbergii community.
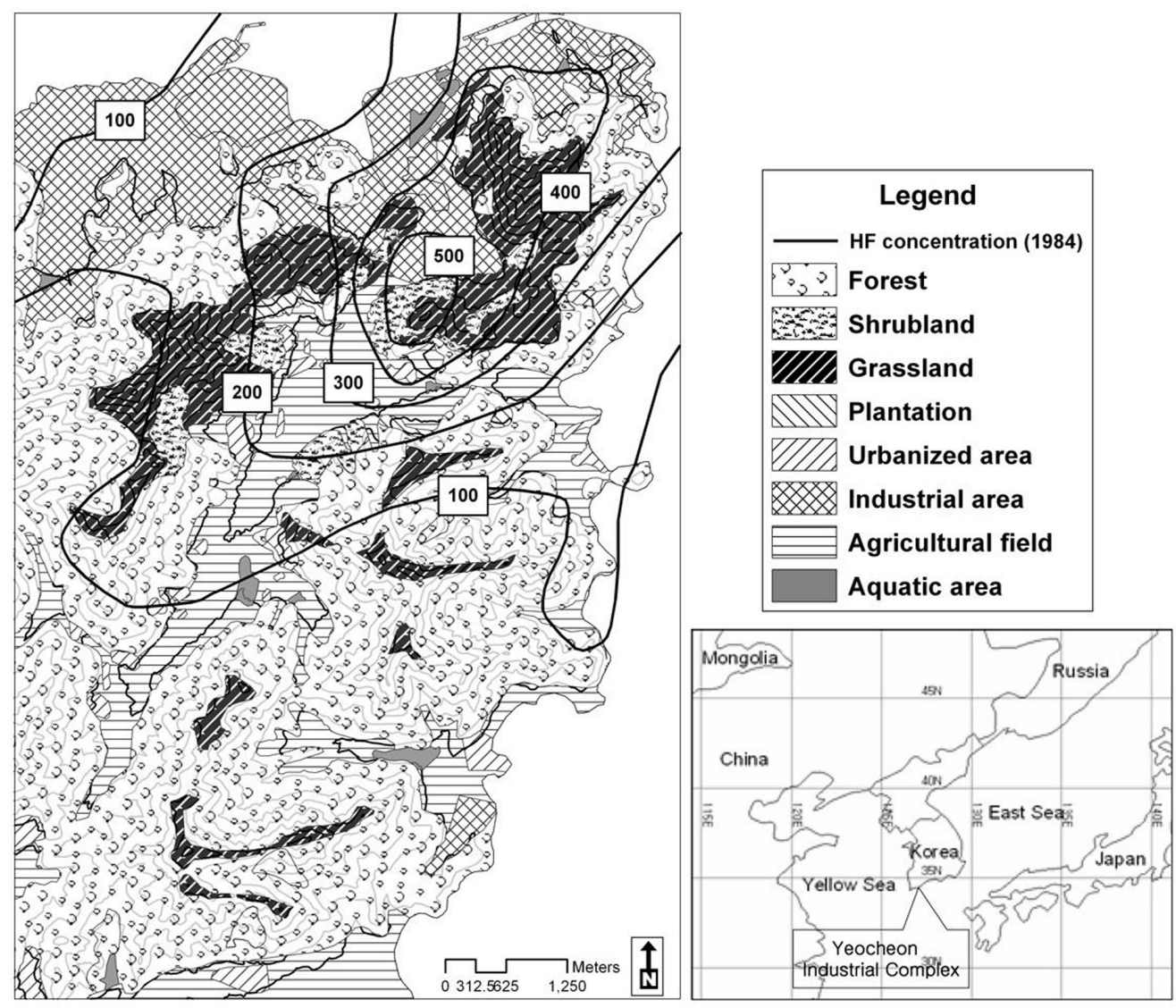

Fig. 2. A map expressed the spatial distribution of vegetation established around the Yeocheon industrial complex. Grassland and shrubland indicate the damaged vegetation. The isopleths lines indicate fluoride concentration (ppb) in needles of the $P$. thunbergii. Fluoride concentration was higher where grassland and shrubland occupy wider area. 
But it was replaced by shrubby stand and grassland of several types since early 1970s when the industrial complex was constructed (Fig. 2).

Distribution pattern of vegetation along the distance from the pollution source, Namhae chemical company, which is an industrial facility producing fertilizer, shows the order of grassland, shrubland dominated by Styrax japonica community, and forest dominated by $P$. densiflora - P. thunbergii. Such a distributional trend might be related to the air pollutants being transported with the land and sea breeze. Grassland was composed of M. sinensis, Phytolacca americana, Pueraria thunbergiana, and Melica onoei communities. Those communities composing of grassland are severely

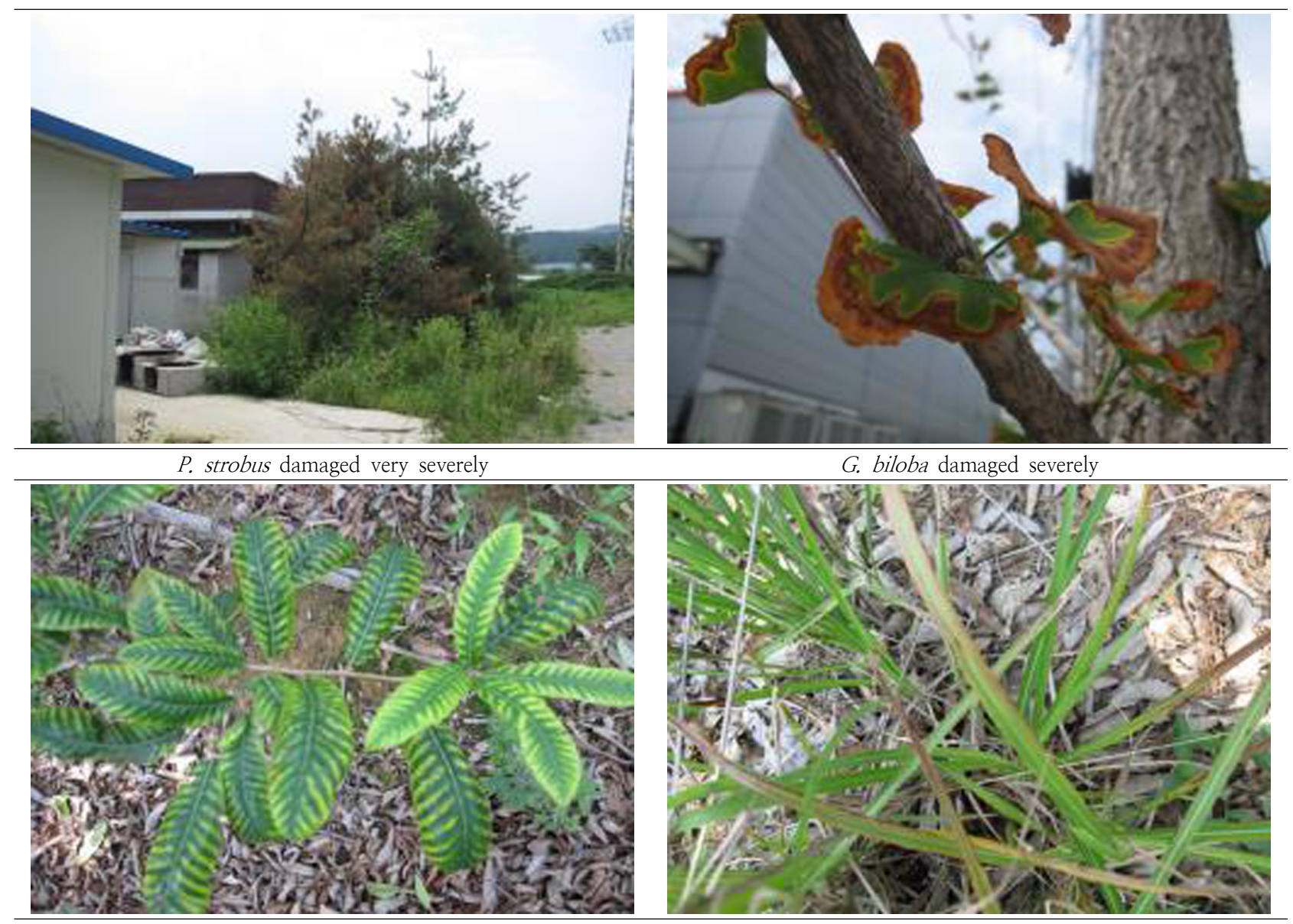

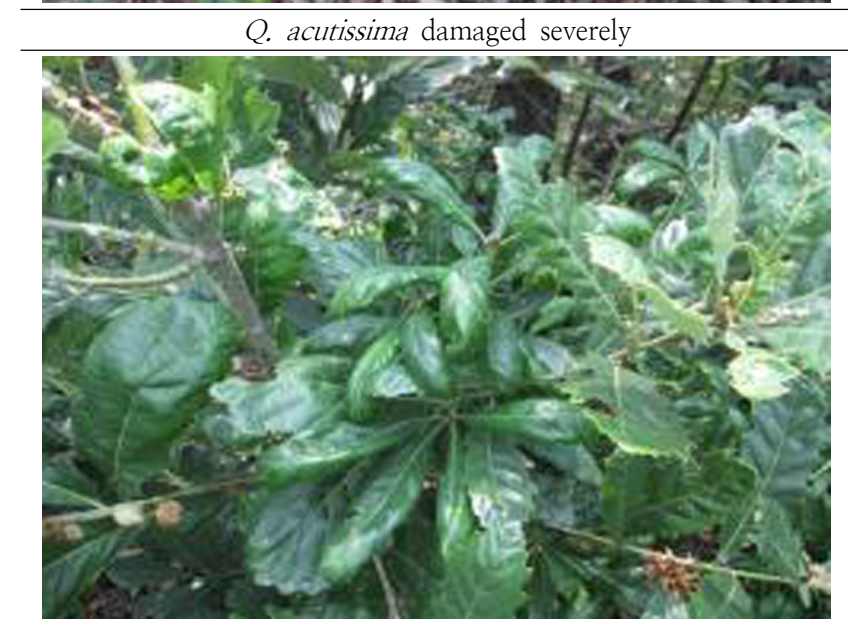

Q. aliena damaged slightly

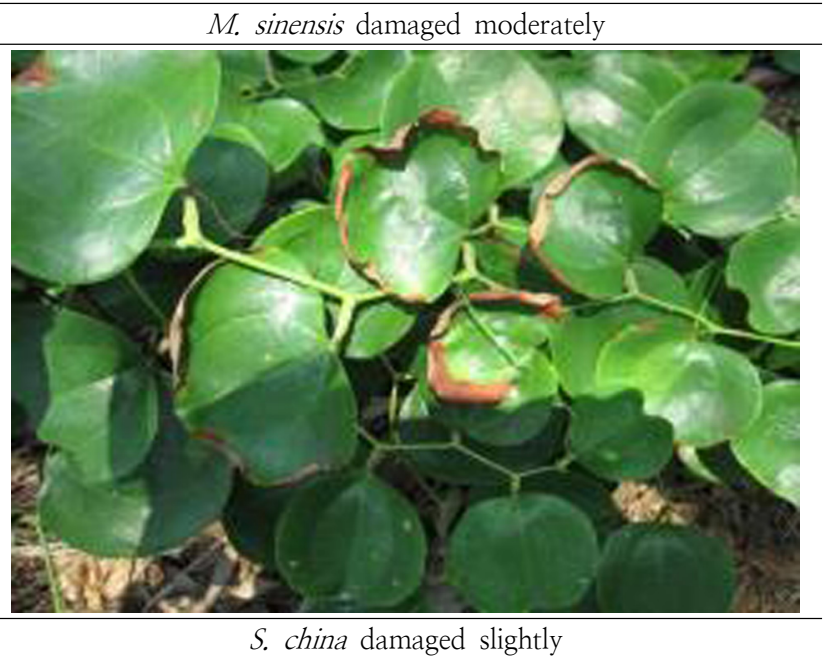

Fig. 3. Photos showing the visible damage shown on leaves of plant species appeared around the spot where hydrofluoric acid is released. Damage degree classified into very severe, severe, moderate, and slight was evaluated based on Lee et al. (2004). 
damaged vegetation types due to severe air pollution. Mixed grasslands tended to distribute in the ridge parts somewhat distant from the pollution source compared with the other grasslands. Shrubland was occurred in the areas, which are near to the pollution source but the effects of air pollution are mitigated by topographic conditions, such as valley, in the faced slope and mid-slope in the opposite one to the pollution source. Forest was established in the areas, which are distant from the pollution source or are in light air pollution by topographic conditions, such as the mountain foot of the opposite slope to the pollution source (Lee et al., 2004, 2007).

Zone where HF concentration is more than 400 ppb was dominated by grassland and areal size of shrubland became similar with that of grassland in concentration range between 200 and $400 \mathrm{ppb}$. On the other hand, forest dominated zone within $100 \mathrm{ppb}$ in HF concentration (Fig. 1).

HF concentration in the air on the day of the accident around the Hube Globe in Gumi was estimated at 1,600 to $3,100 \mathrm{ppb}$ and 500 to $700 \mathrm{ppb}$ within and beyond $500 \mathrm{~m}$ from the accident spot (Gu et al., 2013). The concentrations were 4.0 to 7.8 times and 1.3 to 1.8 times higher compared with concentration of the site covered with grassland, the most severely damaged vegetation type in the Yeocheon industrial complex in 1984 when vegetation damage due to air pollution was very severe (NIER, 1984). Severe plant damage confirmed in this area reflects the result (Fig. 3).

\subsection{Consideration for restoration of ecosystem damaged by $\mathrm{HF}$ gas}

As was shown in Table 1, all the plants appeared around the Hube Globe in Gumi showed damage on their leaf surface even though the hydrofluoric acid leak accident was occurred before one year. This result means that fluoride damage still persists in this year as well. In fact, fluoride remains for a long time in air, soil and water and exerts negative effects at all levels of an ecosystem (Baunthiyal and Ranghar, 2013). In this respect, a restoration plan to remove those negative effects is needed urgently.

Restoration plan was prepared in two viewpoints. The one was prepared in terms of soil amelioration and the other was in a viewpoint of the introduction of tolerant plants. In plants exposed to the fluoride gas in the vicinity of a phosphate fertilizer manufacturing plant, the distribution of leaf $\mathrm{F}$ and $\mathrm{Ca}$ showed a considerable increase with time until the moment, when maximum leaf $\mathrm{F}$ coincided with a drop in $\mathrm{Ca}$ content (Abdallah et al., 2006). Accumulation of $\mathrm{F}$ was found in the leaf margins along with a parallel accumulation of Ca. Necrosis becomes evident when a fall in Ca occurs with an excess of F. The tendency of plant to air fluoride pollution to balance the fluoride accumulation by a parallel calcium accumulation in its leaf margins suggests trapping of fluoride in the form of $\mathrm{CaF}_{2}$. Therefore, tolerant plants accumulating high leaf fluoride content are able to sequester it, as $\mathrm{CaF}_{2}$ (Abdallah et al., 2006). When trapped in this form, fluoride cannot disturb the plant metabolism (Machoy-Mokrzynska, 1995).

$\mathrm{Mg}$ also implicates in a detoxification mechanism trapping fluoride in the form of $\mathrm{MgF}_{2}$. Both mechanisms allow the plant to maintain its $\mathrm{Ca}$ and $\mathrm{Mg}$ concentrations at an adequate level compatible with its survival under such challenging conditions (Abdallah et al., 2006). The interaction of fluoride has also been reported with other cations such as silicon (Charlot and Kisman, 1983) and aluminium (Konishi and Miyamoto, 1983).

Since fluoride exclusion from protoplasm and cellular fluids is most likely to be as insoluble $\mathrm{CaF}_{2}$ (MachoyMokrynska, 1995), the coincidence of the decline in Ca content with the appearance of the first leaf necrosis points to the role played by $\mathrm{Ca}$ in detoxifying $\mathrm{F}$. When no more $\mathrm{Ca}$ is available, probably corresponding to its fall, damage seems to appear in the form of necroses. In the HF polluted environment, $\mathrm{Mg}$ might be taken from the chlorophyll molecule as $\mathrm{MgF}_{2}$, thus possibly explaining the decrease of chlorophyll concentrations and net photosynthesis as the percentage of leaf necroses increases with time (Abdallah et al., 2006). This reduction in chlorophyll as leaf necrosis increases may also reflect the breakdown of membrane structure within the chloroplasts or the direct effects of $\mathrm{F}$ on chlorophyll biosynthesis (Miller, 1993).

On the other hand, the increase of phosphorus (P) can also be a strategy to minimize damage by F. Moreover, it is known that $\mathrm{Mg}$ is a key component for the activity of enzymes involved in the transfer of phosphate (George, 1993).

Considered those facts, we recommend fertilizing of dolomite including $\mathrm{Ca}$ and $\mathrm{Mg}$ together as one of the restoration plans. Further, as Abdallah et al. (2006) also point out, we would like to suggest phosphate fertilizing in order to enhance soil ameliorating effects.

Weinstein and Davison (2003, 2004) reported that 
highly sensitive categories include plants that show visible injury at the farthest distance from the source, while non-sensitive (tolerant) plants show little or no injury even when they are adjacent to the source. Based on this criterion, $Q$. aliena, $P$. coreana, $S$. china, $A$. hirta, A. altissima, and $R$. pseudoacacia could be regarded as tolerant plants to hydrofluoride gas.

We recommend a restoration by introducing tolerant plants as the second measure to mitigate fluoride damage. Lee et al. (2004) selected tolerant plants to restore the forest ecosystem damaged by severe air pollution around the industrial complexes. Lee et al. (2007) practiced a restoration of the forest ecosystem damaged by severe air pollution around the industrial complexes by applying soil ameliorators and tolerant plants. As a tolerant plant to make new forest to replace trees died due to hydrofluoric acid gas damage, we recommend $Q$. aliena. Further, we recommend introducing mantle vegetation to the forest margin. $S$. china, A. hirta, etc. could be recommendable as plant species to create mantle vegetation.

\section{Conclusion}

We could find severe vegetation damage around the Hube Globe in Gumi, where hydrofluoric acid leak accident occurred one years ago. This result means that fluoride damage still persists in this area. And it proves the facts that fluoride remains for a long time in air, soil and water and exerts negative effects at all levels of an ecosystem. In this respect, a measure for removal or detoxification of the remaining fluoride is urgently required around the hydrofluoric acid leak spot. First of all, we recommended soil amelioration plan as a restoration plan to mitigate the continual ecosystem damage. We suggested fertilizing of dolomite containing $\mathrm{Ca}$ and $\mathrm{Mg}$, which can trap fluoride, as one of restoration plans. In addition, we also proposed phosphate fertilizing to enhance soil ameliorating effects. Furthermore, we recommended restoration of damaged forest vegetation by introducing tolerant plants that we selected through field survey as the second measure to mitigate fluoride damage. As the tolerant plants to make a new forest by replacing trees died due to hydrofluoric acid gas damage, we recommended $Q$. aliena. S. china, A. hirta, etc. were recommended as plant species to add mantle vegetation to the forest margin to ensure stable interior environment of the forest. Such ecological restoration based on scientific diagnostic assessment carried out in field could contribute greatly to recover the damaged ecosystem around the accident spot to the integrate and healthy state.

\section{Acknowledgements}

This work was supported by a research grant from Seoul Women's University (2013).

\section{References}

Abdallah FB, Elloumi N, Mezghani, Garrec JP, and Boukhrisb M (2006). Industrial fluoride pollution of Jerbi grape leaves and the distribution of F, Ca, Mg, and P in them. Fluoride 39(1), pp. 43-48.

Baunthiyal M and Ranghar S (2013). Accumulation of fluoride by plants: potential for phytoremediation. Clean - Soil, Air, Water 41(9999), pp. 1-6

Charlot C and Kisman S (1983). Effects de la pollution fluorée sur la répartition des éléments minéraux dans les feuilles et les raciness tubérifiées de radis Raphanus sativa L. Environ Pollut 31, pp. 311-319.

Domingos M, Klumpp A, Rinaldi MCS, Modesto IFm Klumpp G, and Delitti WBC (2003). Combined effects of air and soil pollution by fluoride emissions on Tibouchina pulchra at Cubatão, SE Brazil, and their relations with aluminum. Plant Soil 249, pp. 279-308.

George EF (1993). The components of culture media. In: Plant Propagation by Tissue Culture. Part 1: The Technology. 2nd ed (George EF ed) Edington, Westbury, Wilts, UK.

Gheorghe IF and Ion B (2011). The effects of air pollutants on vegetation and the role of vegetation in reducing atmospheric pollution. In: The Impact of Air Pollution on Health, Economy, Environment and Agricultural Sources (Mohamed K ed), ISBN: 978-953-307-528-0, In Tech, Available from: http://www.intechopen.com/ books/the-impact-of-air-pollution-on-health-econo my-environment-and agricultural-sources/the-effectsof-air-pollutants-on-vegetation-and-the-role-ofvegetation-in-reducing-atmospheric-pollu.

Gu S, Choi I, Kim W, Sun O, Kim S, and Lee Y (2013). Study on the distribution of fluorides in plants and the estimation of ambient concentration of hydrogen fluoride around the area of the accidental release of hydrogen fluoride in Gumi. J. of Environ Health Sci 39(4), pp. 346-353. [Korean Literature with English Abstract]

Haidouti C, Chronopoulou A, and Chronopoulou P (1993). Effects of fluoride emissions from industry on the fluoride 
concentration of soils and vegetation. Biochem. Syst. Ecol. 21, pp. 195-208.

Jacobson JS, Weinstein LH, McCune DC, and Hitchcock AE (1966). The accumulation of fluoride by plants. J. of Air Pollut Control Assoc 16, pp. 412-417.

Konishi S and Miyamoto S (1983). Alleviation of aluminum stress and stimulation of tea pollen tube growth by fluoride. Plant Soil Physion 24, pp. 857-862.

Lee CS, Lee KS, Hwangbo JK, You YH, and Kim JH (2004). Selection of tolerant plants and their arrangement to restore a forest ecosystem damaged by air pollution. Water, Air and Soil Pollution 156, pp. 251-273.

Lee CS, Moon JS, and Cho YC (2007). Effects of soil amelioration and tree planting on restoration of an air-pollution damaged forest in south Korea. Water, Air and Soil Pollution 179, pp. 239-254.

Machoy-Mokrynska A (1995). Fluoride-magnesium interaction. Fluoride 28(4), pp. 175-177.

Mezghani I, Elloumi N, Abdallah FB, Chaieb M, and Boukhris M (2005). Fluoride accumulation by vegetation in the vicinity of a phosphate fertilizer plant in Tunisia. Fluoride 38(1), pp. 69-75.
Miller GW (1993). The effect of fluoride on higher plants with special emphasison early physiological and biochemical disorders. Fluoride 26, pp. 3-22.

National Institute of Environmental Research (NIER) (1984). Studies on the impact of air pollution on the Plants, NIER, Seoul, 276 pp. (In Korean with English summary).

Vike E and Håbj ø rg A (1995). Variation in fluoride content and leaf injury on plants associated with thee aluminium smelters in Norway. Sci Total Environ 163, pp. 25-34.

Weinstein LH (1977). Fluoride and plant life. J. of Occup Med 19, pp. 49-78.

Weinstein LH and Davison AW (2003). Native plant species suitable as bioindicators and biomonitors for airborne fluoride. Environ Pollut 124, pp. 3-11.

Weinstein LH and Davison AW (2004). Fluorides in the Environment: Effects on Plants and Animals. Wallingford, Oxon, UK. 